Ustynova I. P., Husar O. A., Myronets O. M.

UDC 342.98(045)

I. P. Ustynova,

Candidate of Juridical Sciences, Associate Professor

ORCID ID: https://orcid.org/0000-0003-1112-807X

O. A. Husar,

Candidate of Juridical Sciences

ORCID ID: https://orcid.org/0000-0002-0005-7360

O. M. Myronets,

Candidate of Juridical Sciences

ORCID ID: https://orcid.org/0000-0002-5035-2384

\title{
THEORETICAL ISSUES OF A PUBLIC-LEGAL DISPUTE CONCEPT IN THE PROCESS FOR APPEALS AGAINST DECISIONS OF COMPETITIVE SELECTION COMMISSIONS OF ECONOMIC ENTITIES' HEADS IN THE STATE SECTOR OF ECONOMY
}

\author{
National Aviation University \\ Liubomyra Huzara Avenue, 1, 03068, Kyiv, Ukraine \\ E-mails: ustynova1970@gmail.com,gusar_oa@ukr.net,o.m.myronets@ukr.net
}

Purpose: to investigate the current mechanism for appeals against the decision of the competitive selection commissions of economic entities' heads in the state sector of economy as a type of a public-legal dispute and to express an opinion on the regulation of these relations in Ukraine. Research methods: general-scientific and special-legal methods of scientific knowledge, in particular: system-structural and functional methods, method of observation, method of generalization, methods of analysis and synthesis have been applied. Results: the current normative regulation of the procedure for appeals against the decision of the competitive selection commissions of economic entities' heads in the state sector of economy as a type of a public-legal dispute has been analyzed and the judicial practice has been assessed. Discussion: there is a significant lack of scientific research on appeals against the decision of the competitive selection commissions of economic entities' heads in the state sector of economy as a type of a public-legal dispute. This issue has not been considered in many aspects, and various objective indicators have not been taken into account, so the level of research on the theme is low. This is due to the novelty of this theme, as appeals against the decisions of competitive commissions in the public (administrative) process are from the beginning of 2020. Previously, this type of relations was considered only in the context of civil law.

Keywords: a public-legal dispute; appeals against decisions of competitive commissions; competitive commissions; competitive selection commissions; administrative proceedings; heads of state enterprises.

Problem statement and its topicality. The topicality of the research is predisposed by the need for the theoretical investigation of the issues concerning the appeals against the decision of the competitive selection commissions of economic entities' heads in the state sector of economy as a type of a public-legal dispute and the assessment of the mentioned issue normative regulation.
Analysis of recent research and publications. The theme of public law dispute was studied by a large number of domestic scholars in the sphere of Administrative Law, who established the concept of public law and identified its main characteristics, including: V.B. Averyanov, V.M. Bevzenko, V.K. Kolpakov, G.O. Kolomoyets, Yu.B. Bityak, A.V. Makarenko, I.P. Ustynova, O.I. Tapenko, M.H. Toftul, O.I. Kharytonova, N.A. Khleborob, 
O.M. Yakuba, and others. The issues concerning the appeals against the decision of the competitive selection commissions of economic entities' heads in the state sector of economy do not have a wide study.

The purpose is to study and establish the procedure for appeals against the decision of the competitive selection commissions of economic entities' heads in the state sector of economy as a type of a public-legal dispute; to analyze the judicial practice to recognize the decisions of the competitive selection commissions of economic entities' heads in the state sector of economy legal or illegal.

Main material. With the rapid development and the change of legislation in our country, the question of ensuring the direct effect of protection through implementation and constitutionality has become very acute. Currently, despite the antiquity of independence, work on establishing and adapting legislation to Ukrainian realities is still ongoing, so the huge amount of offences and crimes forces us to act more globally and progressively.

In recent years, along with the traditional disputes, which are resolved in civil, commercial and criminal proceedings, there have been many disputes of a related nature, which have the characteristics, including public-legal disputes. This is due to the spread and progress of various social relations, which in one way or another affect the publicadministrative sphere, as well as detailed analysis by the judicial authorities of cases concerning the substantive jurisdiction of this or that dispute. Thus, we can say that today there is a tendency to "expand the scope" of public-legal relations.

As an example of such an "extension" of publiclegal disputes, administrative courts can consider cases related to the activities and decisions of competitive commissions for the appointment of state entities' directors in the state sector of economy. This type of legal relations has related attributes to civil proceedings, and more specifically with labor proceedings.

Until the end of 2019, disputes on appeals against the decisions of these competitive commissions were considered in civil proceedings, until the Supreme Court in the panel of judges of the Administrative Court of Cassation in its decision in case № 826/8950/18 of 24.12.2019 did not distinguish clear criteria for relations of public-legal and private-legal nature [1]. In this decision, the Supreme Court stated that the decisions of competitive commissions for the position of state entities' directors in the state sector of economy should be considered in administrative rather than civil proceedings, as it was before.

The nature of a public-legal dispute is quite extensive and heterogeneous, and the relations that are currently subject to administrative proceedings have many features of other branches of law. To establish the nature of disputes, it is necessary to take into account a considerable number of criteria and signs of their delimitation. In addition, to establish the definition of a public-legal dispute and its distinctive qualities between other types of disputes, it is crucial and necessary to establish a subject of a public-legal dispute.

The opinions of domestic scholars on the subject of a public-legal dispute are not identical, and therefore they deserve comprehensive research and analysis. Thus, V.B. Averyanov refers to the subject of public law relations that are formed:

a) during state governing of economic, sociocultural and administrative-political spheres, as well as the exercise of executive powers delegated by the state to bodies of local self-government, public organizations and some other non-governmental institutions;

b) during the activity of executive bodies and local self-government bodies, their officials to ensure the implementation and protection in the administrative order of the rights and freedoms of citizens, providing them and legal entities with various administrative (managerial) services;

c) in the process of internal organization and activity of the staff of all state bodies, administrations of state enterprises, institutions and organizations, as well as in connection with the passage of state service or service in local self-government bodies;

d) in connection with the exercise of the jurisdiction of administrative courts and the restoration of violated rights of citizens and other subjects of Administrative Law;

e) in the application of measures of administrative coercion, including administrative liability, in respect of individuals and legal entities [2]. 
V.K. Kolpakov, in turn, emphasizes that the subject of a public dispute is not all administrative relations, but only those that are formed as a result and in connection with the performing of executiveadministrative functions by state administration bodies. In his opinion, administrative-legal relations should be characterized by the following attributes:

a) arise only as a result of state-administrative (power) activity;

b) an executive-administrative body of the state necessarily participates in them;

c) they are always a consequence of conscious, purposeful, volitional activity on behalf of the state [3].

We think that the opinions of V.B. Averyanov and V.K. Kolpakov are similar. Both scholars determine that public-legal disputes arise in the governing sphere, and relate to the results of bodies of state power (including executive, judicial), and the relations that have developed as a result of such an activity.

Instead, from the mentioned above, we can conclude that V.K. Kolpakov specifies in more detail the subject of a public-legal dispute, and warns that this type of legal relations cannot include all relations that have developed as a result of a publicgoverning activity. We think that the position of V.K. Kolpakov is more detailed, and specifies the cases when a particular legal dispute can be considered as a public-legal one.

V.M. Bevzenko noted that there are six main types of public-legal (administrative-legal) disputes, and this list correlates with the novelties of the Code of Administrative Proceedings of Ukraine [4].

It is needed to consider how all of the mentioned above exists in the activity of competitive commissions for the appointment of state entities' directors in the state sector of economy. It is a temporary or a permanent organization of employees of a governmental subject and, in cases provided by the law, professional consultants, which is created by the government subject to hold a competition to replace a state entities director in the state sector of economy, which in turn is created without a separate status of a legal entity.

Commissions for competitive selection of economic entities' heads in the state sector of economy in their activities are guided, respectively, by the Procedure for competitive selection of economic entities' heads in the state sector of economy, approved by the Cabinet of Ministers of Ukraine dated September 3, 2008, № 777 (as amended by the Cabinet of Ministers Of Ukraine dated November 15, 2019, № 927).

Competitive selection commissions of economic entities' heads in the state sector of economy may be permanent or temporary:

for a temporary competitive commission, the basis of its activity is a governing subject's order to provide competition to get a director's vacant position of this or that state enterprise, which will approve the composition of the commission;

for a permanent commission, the basis of its activity is an order on the establishment of a permanent competitive commission for the appointment to the position of a state enterprise's director in the sector of economy.

The activity of commissions for competitive selection of economic entities' heads in the state sector of economy is established by paragraph 3 of the relevant regulation [5], and has the following powers:

develops and approves the requirements for persons who have expressed a desire to participate in the competitive selection (hereinafter - the applicants), the criteria for their evaluation;

publishes on the official website of a governing subject not later than within five days after approval of the requirements for applicants, the announcement of the competitive selection for the position of head of an enterprise, which became vacant (hereinafter - the announcement), and the results of competitive selection no later than within three working days from the date of its completion;

accepts, registers and checks for compliance with the requirements of this Procedure the documents and suggestions submitted by applicants;

sends together with the consent to the processing of applicants' personal data a request to the National Police regarding the provision of information on the absence (presence) of their criminal record, a prohibition to hold relevant positions or engage in certain activities; 
decides on the admission of applicants to the competitive selection or rejection of their candidacies;

considers documents and suggestions with an enterprise administration, submitted by participants in the competitive selection;

ensures the openness of the competitive selection and on the basis of the evaluation results concerning participants according to the approved criteria by voting determines its winner.

Thus, taking into account the competitive commission's powers, we note that the peculiarities of its activity depend on those powers. It means that the implementation of the process of exercising its powers by the competitive commission within its competence, with the achievement of a clearly defined goal that is the appointment of the enterprise's director in the sector of economy to the position, taking into account all special rules and limits established by the law, will be a competitive commission's particularity. We see that the status of the competitive commission completely coincides with the main theoretical components of determining the subject of the public-legal dispute.

The subject of public-legal disputes is represented by the relations formed in the direct activity of public authorities, bodies of local self-government, or other bodies endowed with plenary power, if at least one of those relations participant is a member of the executive-managerial body of the state (and acts in those relations on behalf of the state).

The current Code of Administrative Proceedings of Ukraine agrees with the mentioned above delimitation and defining of the subject of the public-legal dispute because as it is known, disputes arising in the public-legal sphere belong to public disputes, which is regulated by Art. 19 of the Code of Administrative Proceedings of Ukraine [6].

In our opinion, public-legal relations have the following attributes:

the relations arise through the direct activity of public authorities, bodies of local self-government, or other bodies of public-plenary power;

at least one side of public-legal disputes is represented by subjects endowed with public-plenary power or are representatives of public authorities, bodies of local self-government or other bodies car- rying out their activities aimed at performing state functions;

the sphere of the public-legal relations' origin (and further the administrative dispute) is due to the direct implementation of the public interest or protection of other persons' interests, which have been violated as a result of the public-legal activity and/or decisions;

the subject of the public-legal disputes is represented by the subjects' of public-legal relations decisions, actions or omissions, which violate or may violate other subjects' rights, freedoms and interests.

Having established the nature, the subject, the attributes of public-legal relations, it is finally possible to formulate the concept of public-legal relations, also referring to the opinion of domestic scholars and judicial practice.

According to V.B. Averyanov, a public-legal dispute is a consequence of the emergence of specific legal relations "a body of public power (an official) - a non-governmental subject of public relations", "a body of public power (an official) - a body of public power (an official)", "a body of public power (an official) - a public officer" [7]. The scholar notes and the authors share his point of view that the main attribute of public-legal relations is that they are based on the conflict of its sides, and therefore the mentioned relations belong to a conflict type. As the above-mentioned researcher explains in his scientific works, the public-legal relations are independent in their meaning and legal nature but derived from non-conflicting legal relations, in which a large number of different subjects of public branches of law participate.

Taking into account the above opinion of V.B. Averyanov, the scientist Yu.B. Bytyak defines types of conflict relations. It arises as a result of an offence committed by an individual or a legal entity, which are acts that violate the rights, freedoms, and legitimate interests of individual subjects of public-legal relations and the general public interest. The state, represented by authorized bodies (officials, other institutions) responds to the commission of administrative offences by virtue of a statutory obligation (status particularities) [8]. Publiclegal relations are conflict in nature, and as it was noted earlier, arise in the exercise of plenary power. 
Also, it should be emphasized that the opinion of V.B. Averyanov that the other side of the conflict does not always want to be its side, is quite interesting because most often those relations arise due to intentional or negligent violation of another person's interests or freedoms [8].

In this case, there are relations of the so-called "delict type". Another type of conflict-type legal relations is recognized as those that arise as a result of the violation by a subject of plenary power (another subject performing power governing functions) of another subject of Administrative Law rights, freedoms and interests [3].

Thus, the decision appeal of competitive selection commissions of economic entities' heads in the state sector of economy can be called public-legal, because the reason for its occurrence, in our opinion, is represented by: abuse of power and, consequently, the violation of non-governmental subjects' rights, who suppose that officials act illegally, as well as conflicts of legal norms in the law or the by-law.

Also, to establish the true concept of publiclegal disputes, one should refer to the latest resolutions of the Supreme Court. By the way, it should be noted that when disclosing the issue of publiclegal relations, one should be guided only by the latest juridical practice, because the "framework" of public-legal relations expands with time, and some other cases, on the contrary, are transferred to civil courts.

Thus, as it is noted by the Supreme Court of Ukraine in the decision of 05.07.2017 in the case № 377/232/16-ts, in accordance with paragraph 1 part 1 of Article 3 of the Code of Administrative Proceedings of Ukraine a case of administrative jurisdiction is a transferred to the administrative court public-legal dispute, in which at least one of the sides is an executive body, a body of local selfgovernment, their official or office-bearer, another subject that performs power governing functions on the basis of legislation, including the exercise of delegated powers [9].

A characteristic feature of public-legal disputes is the sphere their occurrence that is public-legal relations, id est social relations provided by the rules of public law, expressed in mutual rights and duties of their participants in various spheres of so- cial activity, including related to the implementation of public power [9]. A dispute arising from claims based on public law rules is also considered to be a public-legal, where the state, represented by the relevant bodies, acts in relation to a citizen, not as an equal party in legal relations, but as a bearer of sovereign power who may indicate or prohibit certain behavior, give permission for the activity provided by the law, etc. [10]. Thus, the defining feature of administrative-legal relations is the authoritarian subordination of one side of these relations to the other side. The sides in an administrative dispute must be in vertical subordination relations before it arises.

Concerning the competitive selection commissions of economic entities' heads in the state sector of economy decisions appealing, everything is inherent, and therefore may be a theoretical basis for the separation of this type of public dispute.

Thus, public-legal disputes are public relations between individuals and/or legal entities, one of which must be endowed with the plenary powers that occur in the implementation of the state administrative functions, represented by public authorities and/or bodies of local self-government, other bodies endowed with governing functions, and aimed at restoring the violated public-legal interests, individual freedoms.

An appropriate determination of the type of social relations is of paramount importance for the quality, objective and comprehensive implementation of justice. This is due primarily to the correct determination of the subjective jurisdiction, and only later the application of the rules of a particular type of legal relations within this established jurisdiction.

Thus, the subjective jurisdiction of the issue of appeals against the decision of the competitive selection commissions of economic entities' heads in the state sector of economy, as a type of public dispute, is established in accordance with Part 1 of Art. 20 of the Code of Administrative Proceedings of Ukraine. It should be noted that this list is not exhaustive, because it is directly indicated by the legislator in part 2 of Article 20 of the mentioned Code. Decisions concerning the mentioned above types of public-legal relations are made only by local administrative courts, and all other public-legal 
disputes have to be resolved by district administrative courts.

Therefore, having established the subjective jurisdiction of administrative (public) proceedings, we have to consider a completely new type of public relations, which was finally formed in this area only at the end of 2019. It is represented by relations related to the decisions of the competitive selection commissions of economic entities' heads in the state sector of economy. Therefore, before that time, such disputes were considered in the civil law area.

According to the first part of Article 2 of the Code of Administrative Proceedings of Ukraine, the task of administrative proceedings is the fair, impartial and timely resolution of disputes in the field of public-legal relations in order to effectively protect the rights, freedoms and interests of individuals, rights and interests of legal entities from the violation by a subject of plenary power [9].

According to the provisions of part one of Article 19 of the Code of Administrative Proceedings of Ukraine, the jurisdiction of administrative courts extends to cases in public-legal disputes, in particular disputes of individuals or legal entities with a subject of authority to appeal its decisions (regulations or individual acts), actions or omissions, except in cases when the law establishes a different procedure for its judicial proceeding [9].

According to the provisions of the first part of Article 4 of the Code of Administrative Proceedings of Ukraine, a public-legal dispute (a dispute in the field of public-legal relations) is a dispute in which at least one side exercises public-power governing functions, including the exercise of delegated powers, and the dispute arose in connection with the performing or non-performing of the mentioned functions by such a side [9].

The subject of plenary power is a body of state power, a body of local self-government, their official or office-bearer, another subject in the exercise of public-authoritative governing functions under the law, including the implementation of delegated powers, or the administrative services providing.

Thus, the jurisdiction of administrative courts includes disputes between individuals or legal entities with a public authority, a body of local selfgovernment, their official or office-bearer, the sub- ject of which is to verify the legality of decisions, actions or omissions of these bodies (persons) taken or committed by them during exercises of authoritative governing functions. In determining the subjective jurisdiction of cases, the court has to proceed from the essence of a right and/or interest for the protection of which the person applied, the stated requirements, the nature of the disputed legal relations, and the content and legal nature of the circumstances of the case. The defining feature of a case of administrative jurisdiction is the essence (content, nature) of the dispute.

In accordance with the provisions of parts one and three of Article 5 of the Code of Administrative Proceedings of Ukraine, every person has the right to apply to the administrative court in accordance with this Code, if he/she considers that the decision, action, or inaction of the subject of power violates his/her rights, freedoms or legitimate interests, and ask for their protection. Bodies and persons to whom such a right is granted by the law may apply to the administrative court in the interests of other persons.

Moreover, all of the mentioned above is fully in line with the content of the relations to appeal the decisions, actions, and omissions of the competitive selection commissions of economic entities' heads in the state sector of economy.

The subject of court cases concerning the appeal of the existence and activity of the competitive commission are: cancellation of the order on creation of the competitive commission on the appointment of a director of an enterprise of the state sector of economy; cancellation of the order to hold a competition to fill the state-owned enterprise's vacant position of a director.

The appeal of the competitive commission's existence is carried out in accordance with the administrative proceedings. The defendant in the administrative proceedings is a legal entity, a natural person, or a subject of plenary power, which/who carries out own activity on behalf of Ukraine.

At the same time, it should be noted that the competitive commissions for the appointment of the state-owned enterprise's director are not legal entities. Thus, such a commission cannot be a defendant in administrative proceedings. In view of the mentioned above, the defendant in the cases of 
appealing the decision of the competitive commissions for the appointment to the position of director in the state sector of economy is a governmental subject that created such a competitive commission. At the same time, it should be noted that any person whose rights have been violated may appeal to the court against the decision of the commissions for competitive selection of economic entities' in the state sector of economy.

Conclusions. Thus, the competitive commissions' activity results appeal concerning the economic entities' heads selection in the state sector of economy is a kind of public dispute. Therefore it is considered according to the procedural rules of not civil but administrative proceedings. The legislator has fully settled this issue, which corresponds to the juridical practice and basic theoretical developments of juridical science.

\section{References}

1. Верховний Суд України. Постанова у справі № 826/8950/18. 2019. URL: http://www. reyestr.court.gov.ua/Review/86635846 (дата звернення 04.01.2020).

2. Постанова Шостого апеляційного адміністративного суду по справі № 826/8950/18 від 24 груд. 2019 p. URL: https://reyestr.court.gov.ua/ Review/ 86635843 (дата звернення 04.01.2020).

3. Авер'янов В.Б. Адміністративне право України. Академічний курс. Київ: Юридична думка, 2004. $584 \mathrm{c}$.

4. Бевзенко В. Критерії адміністративної юрисдикції. URL: https://sud.ua/ru/ news/blog/ 169927-kriteriyi-administrativnoyi-yurisdiktsiyi (дата звернення 04.01.2020).

5. Порядок проведення конкурсного відбору керівників суб'єктів господарювання державного сектору економіки: затв. постановою Кабінету Міністрів України від 3 вер. 2008 р. № 777 (в ред. постанови КМУ від 15 лист. 2019 p. № 927). URL: https://zakon.rada.gov.ua/ laws/show/777-2008-\% D0\% BF\#Text (дата звернення 04.01.2020).

6. Кодекс адміністративного судочинства України від 6 лип. 2005 р. № 2747-IV. URL: https://zakon.rada.gov.ua/laws/show/2747-15/ed 20170803\#Text (дата звернення 04.01.2020).
7. Авер'янов В.Б. Права громадян у сфері виконавчої влади: адміністративно-правове забезпечення реалізації та захисту. Київ: Наукова думка, 2007. $586 \mathrm{c.}$

8. Битяк Ю.Б., Гаращук В.М., Зуй В.В. Адміністративне право: підручник. Харків: Право, 2013. $656 \mathrm{c}$.

9. Верховний Суд України. Постанова у справі № 377/232/16 ц від 05 лип. 2017 р. URL: http://search.ligazakon.ua/1_doc2.nsf/link1/VS1703 90.html (дата звернення 04.01.2020).

10. Коломоєць Т.О. Адміністративне право України. Академічний курс. Київ: Юрінком Інтер, 2011. 576 c.

11. Колпаков В.К. Адміністративно-правові відносини. Київ: Юрінком Інтер, 2014. 124 с.

12. Постанова Великої Палати Верховного Суду України від 15 трав. 2019 р. у справі № 522/8650/18. URL: http://search. ligazakon.ua/ 1_doc2.nsf/link1/ C008136.html (дата звернення 04.01.2020).

13. Устинова І.П., Лучок А.М. Спори про оскарження рішень конкурсних комісій на призначення директорів підприємств державного сектору економіки як вид публічного спору. Київ: Вид-во НТУ «Київський політехнічний інститут імені Ігоря Сікорського», 2020. 23 с.

\section{References}

1. Verhovnyj Sud Ukrai'ny. Postanova u spravi № 826/8950/18. 2019. URL: http://www.reyestr. court.gov.ua/Review/86635846 (data zvernennja 04.01.2020).

2. Postanova Shostogo apeljacijnogo administratyvnogo sudu po spravi № 826/8950/18 vid 24 grud. 2019 r. URL: https://reyestr.court. gov.ua/ Review/ 86635843 (data zvernennja 04.01.2020).

3. Aver'janov V.B. Administratyvne pravo Ukrai'ny. Akademichnyj kurs. Kyi'v: Jurydychna dumka, 2004. $584 \mathrm{~s}$.

4. Bevzenko V. Kryterii' administratyvnoi' jurysdykcii'. URL: https://sud.ua/ru/ news/blog/ 169927-kriteriyi-administrativnoyi-yurisdiktsiyi (data zvernennja 04.01.2020).

5. Porjadok provedennja konkursnogo vidboru kerivnykiv sub'jektiv gospodarjuvannja derzhavnogo sektoru ekonomiky: zatv. postanovoju 
Kabinetu Ministriv Ukrai'ny vid 3 ver. 2008 r. № 777 (v red. postanovy KMU vid 15 lyst. 2019 r. № 927). URL: https://zakon.rada.gov.ua/ laws/ show/ 777-2008-\% D0\% BF\#Text (data zvernennja 04.01.2020).

6. Kodeks administratyvnogo sudochynstva Ukrai'ny vid 6 lyp. 2005 r. № 2747-IV. URL: https://zakon.rada.gov.ua/laws/show/274715/ed20170803\#Text (data zvernennja 04.01.2020).

7. Aver'janov V.B. Prava gromadjan u sferi vykonavchoi' vlady: administratyvno-pravove zabezpechennja realizacii' ta zahystu. Kyi'v: Naukova dumka, 2007. $586 \mathrm{~s}$.

8. Bytjak Ju.B., Garashhuk V.M., Zuj V.V. Administratyvne pravo: pidruchnyk. Harkiv: Pravo, 2013. $656 \mathrm{~s}$.

9. Verhovnyj Sud Ukrai'ny. Postanova u spravi № 377/232/16 c vid 05 lyp. 2017 r. URL:
http://search.ligazakon.ua/1_doc2.nsf/link1/VS1703 90.html (data zvernennja 04.01.2020).

10. Kolomojec' T.O. Administratyvne pravo Ukrai'ny. Akademichnyj kurs. Kyi'v: Jurinkom Inter, $2011.576 \mathrm{~s}$.

11. Kolpakov V.K. Administratyvno-pravovi vidnosyny. Kyi'v: Jurinkom Inter, 2014. 124 s.

12. Postanova Velykoi' Palaty Verhovnogo Sudu Ukrai'ny vid 15 trav. 2019 r. u spravi № 522/8650/18. URL: http://search.ligazakon.ua/ 1_doc2.nsf/link1/ C008136.html (data zvernennja 04.01.2020).

13. Ustynova I.P., Luchok A.M. Spory pro oskarzhennja rishen' konkursnyh komisij na pryznachennja dyrektoriv pidpryjemstv derzhavnogo sektoru ekonomiky jak vyd publichnogo sporu. Kyi'v: Vyd-vo NTU «Kyi'vs'kyj politehnichnyj instytut imeni Igorja Sikors'kogo», 2020. 23 s. 
Ustynova I. P., Husar O. A., Myronets O. M.

\title{
І.П. Устинова, О.А. Гусар, О.М. Миронець \\ ТЕОРЕТИЧНІ ПИТАННЯ ПОНЯТТЯ ПУБЛІЧНО-ПРАВОВОГО СПОРУ В ПРОЦЕСІ ОСКАРЖЕННЯ РІШЕНЬ КОМІСІЙ КОНКУРСНОГО ВІДБОРУ КЕРІВНИКІВ СУБ'СКТІВ ГОСПОДАРЮВАННЯ ДЕРЖАВНОГО СЕКТОРУ ЕКОНОМІКИ
}

\author{
Національний авіаційний університет \\ проспект Любомира Гузара, 1, 03680, Київ, Україна \\ E-mails: ustynova1970@gmail.com,gusar_oa@ukr.net,o.m.myronets@ukr.net
}

\begin{abstract}
Мета: дослідити чинний механізм оскарження рімень комісії конкурсного відбору керівників суб'єктів господарювання державного сектору економіки як виду публічно-правого спору та висловити думку щодо нормативного регулювання цих відносин в Україні. Методи: застосовані загальнонаукові та спеціально-юридичні методи наукового пізнання, зокрема: системноструктурний і функиіональний методи, метод спостереження, метод узагальнення, методи аналізу i синтезу. Результати: проаналізовано чинне нормативне регулювання процедури оскарження рішень конкурсної комісії керівників суб'єктів господарювання державного сектору економіки як виду публічно-правого спору та дана оцінка судовій практиці. Обговорення: наукових досліджень щодо оскарження рішень комісій конкурсного відбору $з$ призначення керівників підприємств державного сектору економіки як виду публічно-правового спору суттєво бракує. Дана проблематика не була розглянута в багатьох аспектах, та не були враховані різні об'єктивні показники, тому ступінь дослідження теми низький. Це пов 'язано з новизною даної тематики, адже оскарження рішень конкурсних комісій у публічному (адміністративному) прочесі відбувається з початку 2020 року. Раніше даний вид відносин розглядався лише в контексті иивільного права.

Підсумовуючи своє дослідження, автори роблять висновок, щзо оскарження результатів діяльності конкурсних комісій щодо відбору керівників суб'єктів господарювання у державному секторі економіки є своєрідним публічним спором. Тому він розглядається відповідно до прочесуальних норм не цивільного, а адміністративного судочинства. Законодавещь повністю врегулював це питання, яке відповідає юридичній практиџі та основним теоретичним розробкам юридичної науки.
\end{abstract}

Ключові слова: публічно-правовий спір; оскарження рімень конкурсних комісій; конкурсні комісії; комісії конкурсного відбору; адміністративне судочинство; керівники державних підприємств. 